\title{
NOVEL TRENDS IN THE MOLECULAR GENETICS OF HEARING LOSS
}

\section{Urszula Lechowicz, Agnieszka Pollak, Monika Oldak}

Department of Genetics, World Hearing Center, Institute of Physiology and Pathology of Hearing, Warsaw/Kajetany, Poland

Corresponding author: Monika Oldak, Department of Genetics, World Hearing Center, Institute of Physiology and Pathology of Hearing, Mochnackiego Str. 10, 02-042 Warsaw, Mokra Str. 17, Kajetany, 05-830 Nadarzyn Poland, Tel.: +48-22-356-03-66; Fax: +48-22-356-03-67; e-mail: m.oldak@ifps.org.pl

\begin{abstract}
Genetically determined hearing loss is a highly heterogeneous disorder, and to date the analysis of its causes has been conducted selectively, covering only individual genes. Breakthroughs associated with current technological advances have contributed to a rapid development in the molecular genetics of hearing loss. Here we review a number of novel and important achievements in the field: application of next-generation sequencing, novel genes, and trends in molecular therapies for hearing loss. Current achievements in the molecular genetics of hearing loss are discussed in the context of previously published results and data from our own studies.
\end{abstract}

Key words: genetics $\bullet$ hearing loss $\bullet$ NGS technology $\bullet$ molecular biology

\section{NUEVAS ORIENTACIONES EN GENÉTICA MOLECULAR DE LA PÉRDIDA DE AUDICIÓN}

\begin{abstract}
Resumen
La pérdida de audición determinada genéticamente es un trastorno muy heterogéneo. Hasta ahora, el análisis de las causas se basa en el principio de la selectividad e incluye sólo genes individuales. El avance asociado con los progresos en tecnología, contribuyó al rápido desarrollo de la genética molecular de la pérdida de audición. Este trabajo es una revisión de nuevos e importantes desarrollos en el campo de la secuenciación de próxima generación, la identificación de nuevos genes y las tendencias en la terapia molecular de la pérdida de audición. Los avances modernos en genética molecular de la pérdida de audición se describen en el contexto de los resultados publicados anteriormente y los datos obtenidos a partir de la propia investigación.
\end{abstract}

Palabras clave: genética • pérdida de la audición • tecnología NGS • biología molecular

\section{НОВЫЕ НАПРАВЛЕНИЯ В МОЛЕКУЛЯРНОЙ ГЕНЕТИКЕ ТУГОУХОСТИ}

\section{Изложение}

Генетически обусловленная тугоухость является высоко гетерогенным нарушением. Анализ причин до сих пор был основан на принципах селективности и принимал во внимание только отдельные гены. Прорыв, связанный с развитием технологии, повлиял на быстрое развитие молекулярной генетики тугоухости. Настоящая работа - это обзор новых и важных достижений в области секвенирования нового поколения, идентификации новых генов и направлений в молекулярной терапии тугоухости. Современные достижения в молекулярной генетике тугоухости описаны в контексте ранее изданных результатов и данных, полученных в ходе собственных исследований.

Ключевые слова: генетика • тугоухость • технология НГС • молекулярная биология

\section{NOWE KIERUNKI W GENETYCE MOLEKULARNEJ NIEDOSŁUCHU}

\section{Streszczenie}

Niedosłuch uwarunkowany genetycznie jest zaburzeniem wysoce heterogennym. Jak dotąd analiza przyczyn była oparta o zasady selektywności i uwzględniała tylko pojedyncze geny. Przełom, związany z rozwojem technologicznym, wpłynął na szybki rozwój genetyki molekularnej niedosłuchu. Niniejsza praca jest przeglądem nowych i ważnych osiągnięć w dziedzinie 
sekwencjonowania następnej generacji, identyfikacji nowych genów oraz kierunków w terapii molekularnej niedosłuchu. Współczesne osiągnięcia $\mathrm{w}$ genetyce molekularnej niedosłuchu opisano w kontekście wcześniej opublikowanych wyników i danych uzyskanych z własnych badań.

Słowa kluczowe: genetyka • niedosłuch • sekwencjonowanie nowej generacji (NGS) • biologia molekularna

\section{Introduction}

Achievements of the last 20 years in the molecular genetics of hearing loss (HL) have contributed greatly to a better understanding of the pathogenesis of deafness. Clarifying the genetic basis of $\mathrm{HL}$ and recognizing the phenotypic characteristics resulting from certain mutations is of great interest for researchers worldwide. However, the task is difficult because as many as 300 genes might be involved in the proper functioning of the auditory pathway and mutations in any of them can result in hearing impairment [1].

In the standard diagnostic procedure, searching for a genetic basis of HL in patients is usually limited to analysis of the GJB2 gene. In Caucasians the most common mutation responsible for autosomal recessive deafness is a deletion of guanine 35 (c.35delG) in the GJB2 gene, encoding connexin 26. Occasionally, mutations in the GJB6, SLC26A4, MYO15A, or OTOF genes and in mitochondrial DNA (e.g. $\mathrm{m} .1555 \mathrm{~A}>\mathrm{G}, \mathrm{m} .3243 \mathrm{~A}>\mathrm{G}$ ) are tested [2].

Determining the molecular basis of deafness is important both for the patient and for the whole diagnostic and therapeutic process. Knowledge of the genetic basis of hearing impairment might be useful in forecasting the results of treatment or rehabilitation - for example predicting whether use of a cochlear implant might be beneficial. In other situations, the information might be used to prevent the occurrence of phenotypic consequences of certain mutations. An example here is the avoidance of aminoglycoside antibiotics in patients with a confirmed m.1555A $>\mathrm{G} \mathrm{mu-}$ tation in the mitochondrial DNA. This paper sets out current trends in the molecular genetics of hearing loss. The trends include application of next-generation technology (NGS), identification of novel genes, and molecular therapies for hearing loss.

\section{Application of NGS technology: Studies on the genetic background of HL}

Massive parallel sequencing (MPS), also called next-generation sequencing (NGS) developed over the last decade, has drastically reduced the cost and increased the efficiency of DNA sequencing. It has thereby opened up its use to daily clinical practice $[3,4]$. Whole exome sequencing (WES, i.e. sequencing of all the protein-coding genes in a genome), allows one to not only look for mutations in already known genes associated with a particular disease, but also gives the opportunity to discover new genes underlying the disorder being studied. WES technology is considered an effective strategy for the discovery of novel genes, as more than $80 \%$ of disease-causing variants are located in protein-coding regions $[5,6]$.

Another way of identifying the genetic cause of a disease is to perform sequencing of a selected panel of genes. There are many commercial tests based on NGS, which differ in technologies and numbers of genes included (Table 1).

Table 1. Commercial tests for HL based on NGS technology (selected examples)

\begin{tabular}{|c|c|c|c|}
\hline Company & $\begin{array}{l}\text { Genetic tests } \\
\text { for deafness }\end{array}$ & $\begin{array}{l}\text { Number of analyzed } \\
\text { genes }\end{array}$ & Technology \\
\hline Otogenetics Corporation, Norcross, GA, USA & Human deafness panel & 129 & $\begin{array}{l}\text { Illumina sequencing } \\
\text { (MiSeq) }\end{array}$ \\
\hline $\begin{array}{l}\text { Radboud University Medical Center, } \\
\text { Nijmegen, The Netherlands }\end{array}$ & $\begin{array}{l}\text { Hearing impairment gene } \\
\text { panel DGD141114 }\end{array}$ & 126 & $\begin{array}{l}\text { ABI SOLiD sequencing, } \\
\text { Illumina sequencing }\end{array}$ \\
\hline $\begin{array}{l}\text { University of lowa Hospital and Clinics, } \\
\text { Molecular Otolaryngology and Renal } \\
\text { Research Laboratories, lowa City, IA, USA }\end{array}$ & OtoSCOPE version 6 & 116 & Illumina sequencing \\
\hline Fulgent Diagnostics, Temple City, CA, USA & Hearing loss NGS panel & 103 & Illumina sequencing \\
\hline $\begin{array}{l}\text { Center for Human Genetics and Laboratory } \\
\text { Medicine Martinsried, Martinsried, Germany }\end{array}$ & $\begin{array}{l}\text { Hearing loss/deafness } \\
\text { multi-gene panel }\end{array}$ & 91 & $\begin{array}{l}\text { Genotyping (Microarray, } \\
\text { Beads, etc.) } \\
\text { Sequencing, Next Gen }\end{array}$ \\
\hline $\begin{array}{l}\text { Partners HealthCare Personalized Medicine, } \\
\text { Laboratory for Molecular Medicine, } \\
\text { Cambridge, MA, USA }\end{array}$ & OtoGenome panel & 87 & Illumina sequencing \\
\hline $\begin{array}{l}\text { Sistemas Genomicos, Medical Genetics Unit, } \\
\text { Paterna, Spain }\end{array}$ & Familiar deafness & 79 & ABI SOLiD sequencing \\
\hline Asper Biotech Ltd, Tartu, Estonia & $\begin{array}{l}\text { Hearing loss/deafness } \\
\text { multi-gene panel }\end{array}$ & 76 & Illumina sequencing \\
\hline
\end{tabular}


Table 2. Genes with mutations identified by WES in Polish patients with $\mathrm{HL}$

\begin{tabular}{ccc}
\hline Gene & Cases & $\%$ \\
\hline SLC26A4 & 4 & 26.7 \\
\hline TMC1 & 3 & 20.0 \\
\hline MYO15A & 2 & 13.3 \\
\hline WFS1 & 1 & 6.7 \\
\hline TRIOB & 1 & 6.7 \\
\hline TMPRSS3 & 1 & 6.7 \\
\hline POU3F4 & 1 & 6.7 \\
\hline
\end{tabular}

Targeted genomic enrichment (TGE) and massively parallel sequencing to capture the exons of as many as 246 genes was designed and implemented by Brownstein et al. [7]. Currently, the panel has been expanded to 284 genes (121 human genes and 163 human orthologues of mouse HL genes) and applied to 1 Brazilian and 67 Israeli Jewish families with HL. More than 20 genes, particularly TMC1 but also POU3F4, MYO6, and MYO15A, carried pathogenic variants. This work made it possible to solve $38 \%$ of $\mathrm{HL}$ cases in the Jewish Israeli population [8]. The same panel (284 genes) was used among 91 hearing loss families of Arab ethnicity. Novel mutations in 23 known deafness genes were discovered. Additionally in one family who underwent WES a novel hearing loss gene SLC25A21 (coding a solute carrier family 25, member 21, which transports C5-C7 oxodicarboxylates across inner mitochondrial membranes), was identified. In the study, the mutations causing deafness were determined in $32 \%$ of the studied population [9].

French and British groups have used panels of 71 and 67 genes, respectively, among hearing loss patients $[10,11]$. To prepare the libraries, the first group used Illumina Nextera Rapid Capture custom enrichment (Illumina Inc., San Diego, CA, USA) or Nimblegen SeqCap EZ Choice (Roche AG, Basel, Switzerland). In the case of a recessive inheritance of HL, only the proband was tested by NGS. If dominant inheritance was suspected, a minimum of three family members (the patient as well as an affected relative and a control relative) were studied. Except for the mutations in autosomal genes, in which myosin genes dominated, mutations in three already known genes (POU3F4, SMPX, and PRPS1) on the $\mathrm{X}$ chromosome were found [10]. Our unpublished data is consistent with the observation that the POU3F4 gene is a significant cause of X-linked $\mathrm{HL}$ (A. Pollak, in prep.).

The second group applied a custom-designed HaloPlex targeted genomic capture kit (Agilent Technologies Inc., Santa Clara, CA, USA) in 59 British Asians HL patients to screen the coding regions of 67 non-syndromic deafness genes. In 15 cases, pathogenic or possible pathogenic mutations in the GIPC3, LHFPL5, LOXHD1, MYO15A, MYO3A, OTOF, PCDH15, STRC, and TMIE genes were identified [11]. The largest panel of 307 deafness genes was used by the China group to screen 147 DNA samples retrieved from HL patients. Among non-syndromic patients with early-onset HL, the molecular background was determined for $56.6 \%$ of patients, while in the individuals with late-onset HL the causative genes were found in $39.5 \%$ [12].

NGS technology has also been successfully implemented in the Department of Genetics, World Hearing Center, Institute of Physiology and Pathology of Hearing to study mutations in nuclear and mitochondrial genes in patients with HL. For the nuclear genes (WES) we use a Nextera Rapid Capture exome kit (Illumina Inc.), while for the mitochondrial DNA, a Nextera XT DNA Library preparation kit (Illumina Inc.) is applied. Sequencing is performed on both the HiSeq1500 and MiSeq platforms (Illumina Inc.). Our preliminary results reveal that there is no other single gene as frequent as DFNB1 (GJB2/GJB6) in recessive HL (Table 2) [Pollak, in prep.; 13]. Except for GJB2 and GJB6, among the major genes responsible for recessive HL in our patients are SLC26A4, TMC1, MYO15A, and TMPRSS3, and results are comparable with data from other European populations [Lechowicz, in prep.; 14,15].

\section{Novel genes in hearing loss}

One of the newest findings has been the identification of the first gene for autosomal dominant otosclerosis [16]. Despite a number of families with autosomal dominantly inherited otosclerosis, the etiology of the disease has remained unknown $[17,18]$. Ten different genetic loci (OTSC1-10) have been mapped so far (http://hereditaryhearingloss.org), but for none of them any gene has been assigned. A combination of linkage, fine mapping, and exome sequencing in a family from Newfoundland (Canada), led to the identification of a 15-bp in-frame deletion in the FOXL1 gene (NM_005250_c.976_990het_delGGGATCCCCTTCCTC), which causes the removal of five amino acids from the highly conserved C-terminus. The variant completely segregated with the disease in all family members with surgically confirmed otosclerosis [16,19].

Changes in the structure of the FOXL1 protein, which functions as a transcriptional regulator, may ultimately lead to the dysregulation of cytokine expression. This interpretation is consistent with the hypothesis of activated bone remodeling in the middle ear in patients with otosclerosis [20]. Clinical otosclerosis is defined as a bone remodeling disease, characterized by the cementing of the stapes bone to the oval window and considered a major cause of conductive hearing loss in adults. Notwithstanding, the final recognition of the role of FOXL1 in otosclerosis requires 
Table 3. Examples of novel genes associated with hearing impairment identified using WES technology

\begin{tabular}{|c|c|c|c|}
\hline Gene & Method for identification & Studied population & Reference \\
\hline$A D C Y 1$ & $\begin{array}{l}\text { Exome sequencing (Roche NimbleGen SeqCap EZ } \\
\text { Human Exome Library) Illumina HiSeq }\end{array}$ & Pakistani family & {$[27]$} \\
\hline$B D P 1$ & $\begin{array}{l}\text { Exome sequencing (SureSelectXT Human All Exon V5 } \\
\text { (Agilent Technologies, Inc.; Applied Biosystems SOLiD } \\
\text { System-Version 2.0.1) }\end{array}$ & Qatari family & {$[28]$} \\
\hline FAM65B & $\begin{array}{l}\text { Exome sequencing (Agilent SureSelect Human All Exon } \\
50 \text { Mb Kit); Illumina HiSeq } 2000\end{array}$ & Turkish family & [29] \\
\hline HOMER2 & $\begin{array}{l}\text { Exome sequencing (Agilent SureSelectXT Human All } \\
\text { Exon V4) Illumina HiSeq } 2000\end{array}$ & European family & [30] \\
\hline MCM2 & $\begin{array}{l}\text { Exome sequencing (Illumina TruSeq } 62 \mathrm{Mb} \text { Exome } \\
\text { Enrichment kit); Illumina HiSeq } 2000\end{array}$ & Chinese family & [31] \\
\hline MET & Whole-exome sequencing & Pakistani family & [32] \\
\hline NARS2 & $\begin{array}{l}\text { Exome sequencing (Illumina TruSeq Exome } \\
\text { Enrichment Kit; Roche NimbleGen SeqCap EZ Exome } \\
\text { Library v2.0) Illumina HiSeq } 2000\end{array}$ & $\begin{array}{l}\text { Pakistani and Caucasian } \\
\text { families }\end{array}$ & [33] \\
\hline$P 2 R X 2$ & $\begin{array}{l}\text { Exome sequencing (Agilent SureSelect Target } \\
\text { Enrichment system); Illumina HiSeq2000 }\end{array}$ & Chinese family & [34] \\
\hline$T B C 1 D 24$ & $\begin{array}{l}\text { Exome sequencing (Illumina TruSeq Exome } \\
\text { Enrichment Kit) Illumina HiSeq } 2000\end{array}$ & Chinese family & [35] \\
\hline TMEM132E & $\begin{array}{l}\text { Exome sequencing (Roche SureSelect Human All Exon } \\
\text { Kit) Illumina HiSeg } 2000\end{array}$ & Chinese family & [36] \\
\hline
\end{tabular}

further studies. For a pathogenic dominant variant, the frequency of the identified FOXL1 mutation in the general population is unexpectedly high $(0.16 \%$ in Europeans and $0.09 \%$ in Africans) [16]. In an autosomal dominant disease model, variants with an allele frequency of $<0.1 \%$ are considered potentially pathogenic.

Another remarkable finding relates to the PSIP 1 gene, which for the first time has been found to cause HL. Whole exome sequencing from an Italian family identified a frameshift deletion leading to a premature stop codon (c.1554_1555del, p.E518Dfs², p.T519X) in the PSIP1 gene. Among studied family members, the mutation segregated with sensorineural progressive hearing loss at medium-high frequencies and with various eye phenotypes, such as uveitis and optic neuropathy. Additional data demonstrated that this mutation does not cause mRNA degradation, despite the introduction of a premature stop codon [21]. Psip1 is expressed in the nuclei of hair cells and supporting cells in the mouse cochlea, but it has not been identified in the auditory nerve. The protein encoded from the gene seems to function as a transcriptional co-activator in the cochlea and a possible protector against photoreceptor degeneration in the eye $[22,23]$.

Quite recently, PEX1 and PEX6 genes have been identified as a molecular cause of Heimler syndrome (HS) [24]. Whole exome sequencing among eight families with HS pinpointed biallelic mutations in PEX1 or PEX6 genes in six affected families. The syndrome is a rare recessive disorder [25] which was described for the first time in 1991 in a brother and sister who had profound sensorineural hearing deficiency, enamel hypoplasia limited to the permanent dentition, and nail abnormalities [26]. Mutations in PEX1 and PEX6 have, so far, been detected only in patients with peroxisome biogenesis disorders (PBDs) such as Zellweger syndrome. Interestingly, in samples collected from affected family members (plasma, erythrocytes, and cultured skin fibroblasts), no significant changes in biochemical peroxisomal parameters were found. Nonetheless, a mosaic peroxisomal pattern, manifesting in mild peroxisomal dysfunction, was detected at the cellular level using immunofluorescence microscopy [24]. This study reveals the phenotypic heterogeneity of $P E X$ mutations.

Beside the above-mentioned genes associated with hearing impairment, in the last few years many novel HL genes have been identified (summarized in Table 3).

\section{Evaluation of existing knowledge}

An extremely important issue, triggered by the NGS technology, is evaluation of the existing knowledge. The efforts are particulairy focused on the role of different genes in the disease pathogenesis. In the field of HL, at least two genes have been excluded from the "pathogenic list" over the last years. The first report questioned the role of $R A$ $B 40 A L$ mutation as a disease-causing change involved in Martin-Probst syndrome (MPS). RAB40AL had been identified at the locus of MPS, an X-linked deafness / intellectual disability syndrome, based on linkage studies, segregation of a missense change p.D59G in the gene with the disease in a single family, and in vitro localization studies [37]. However, we have found a high prevalence of the p.D59G variant $(2.47 \%)$ in the general Polish population, which allows us to exclude the role of the RAB40AL mutation as a disease-causing change in MPS and the involvement of RAB40AL in MPS [38,39]. 
In another report, the pathogenic role of the MYO1A gene, which was previously considered an essential gene causing autosomal dominant nonsyndromic hearing loss DFNA48, was challenged [40]. The studied patients and also their unaffected relatives were found heterozygous for two novel nonsense (p.Tyr740* and p.Arg262*) and a known missense variant in the MYO1A gene. Interestingly, among those families deafness was caused by mutations in other genes (MYO7A, EYA1, and CIB2). Based on these findings, and a high prevalence of previously reported $M Y$ $O 1 A$ mutations in the general population, the evidence for its pathogenic potential in HL is currently lacking [41].

\section{Perspectives and state of the art therapies}

Efforts to repair and restore the function of sensing cells in the inner ear have significantly intensified over the last 10 years. The inner ear hosts a number of specialized cells, and their regeneration is a potential target for new therapies of HL. In a properly functioning auditory pathway, all cell types must be present and functional. While restoring the perception of sound over the whole auditory pathway would be the most worthy goal, experience learnt from the use of cochlear implants shows that even partial recovery of a missing element in the pathway may be sufficient to restore some aspects of sound perception. Currently, the most intense research is being carried out using three strategies: stem cells, molecular therapy, and gene therapy.

With these three methods, researchers are trying to restore hearing at the cellular level. An example of such new therapies is an effort to find a method to treat the DFNB1 type of deafness caused by mutations in the GJB2 gene. In vitro studies are promising, showing that transfer of a normal Gjb2 gene in the mouse can restore functionality of connexons [42]. These studies are a precursor to future strategies aimed at restoring the function of gap junctions, an approach which could improve hearing among many patients with a genetic background of HL.

There are also attempts to use gene therapy to restore the functionality of spiral ganglion neurons (SGNs). Since cochlear implants stimulate the SGNs directly via electrical impulses, survival of these neurons is a prerequisite for successful cochlear implantation. In animal models, many viral vectors have been successfully used to transfer the gene encoding BDNF (Brain Derived Neurotrophic Factor) into the cells of the inner ear, enabling their shortterm survival [43], but it is uncertain whether this method will be effective in the long term.
Another active area of research are attempts to produce new hair cells in mammals. Experiments have been carried out to convert endogenous supporting cells into hair cells, mostly through principal regulatory elements such as transcription factor ATOH1 (Atonal Homolog 1 (Drosophila)), which is required for proper cell differentiation. Atoh1 transfection into mouse inner ear appears promising, as such mice were able to obtain functional hair cells $[44,45]$. In cochleas with hair cells damaged from noise exposure, expression of the Atoh1 gene induced repair of these cells [46]. This approach might help in the treatment of hearing loss caused by acute acoustic trauma (e.g. after exposure to intense noise). In such a case, treatment would need to be initiated within a short time. In 2014 the US FDA (Food and Drug Administration) approved for clinical human trials the delivery of the $A T O H 1$ gene into supporting cells of the inner ear via an adenovirus. Details of the study have been reported by the participating companies, Novartis (Switzerland, Basel) and GenVec (USA, Gaithersburg), at https://clinicaltrials.gov/ct2/home.

Attempts to restore hearing using the strategies described above require precise knowledge of the actions of the individual components of the auditory pathway at the cellular level. The corollary of this is that detailed studies of the properties and activities of proteins, RNAs, and genes associated with hearing loss are essential.

\section{Summary}

Isolated, congenital deafness is the most common monogenic disorder and in $80 \%$ of cases it is inherited in an autosomal recessive manner. Mutations in GJB2 are responsible for the occurrence of this type of hearing loss in most Caucasian populations; therefore routine diagnostic tests among HL patients have been focused on analyzing this gene. Currently, for patients who have a suspected genetically based HL, and where GJB2 mutation has been excluded, a reasonable diagnostic option is the use of NGS technology, either as WES or a panel of selected genes. WES allows a genetic background of HL to be identified in about half of all HL patients, although the cause of the remaining half still needs to be uncovered.

This work was supported by the Polish National Science Center (grants 2012/05/N/NZ5/02629 and 2011/03/D/ NZ5/05592) and the project "Integrated system of tools designed for diagnostics and telerehabilitation of sense organ disorders (hearing, vision, speech, balance, taste, smell)" INNOSENSE, co-financed by the National Centre for Research and Development within the STRATEGMED program.

\section{References:}

1. Friedman TB, Griffith AJ. Human nonsyndromic sensorineural deafness. Annu Rev Genomics Hum Genet, 2003; 4: 341-402.

2. Hilgert N, Smith RJ, Van Camp G. Forty-six genes causing nonsyndromic hearing impairment: which ones should be analyzed in DNA diagnostics? Mutat Res, 2009; 681(2-3): 189-96.

3. Clark MJ, Chen R, Lam HY, Karczewski KJ, Chen R, Euskirchen $\mathrm{G}$ et al. Performance comparison of exome DNA sequencing technologies. Nat Biotechnol, 2011; 29(10): 908-14.
4. Zhang J, Chiodini R, Badr A, Zhang G. The impact of nextgeneration sequencing on genomics. J Genet Genomics, 2011; 38(3): 95-109.

5. Chen JM, Ferec C, Cooper DN. Revealing the human mutome. Clin Genet, 2010; 78(4): 310-20.

6. Ng SB, Turner EH, Robertson PD, Flygare SD, Bigham AW, Lee $\mathrm{C}$ et al. Targeted capture and massively parallel sequencing of 12 human exomes. Nature, 2009; 461(7261): 272-6. 
7. Brownstein Z, Friedman LM, Shahin H, Oron-Karni V, Kol N, Abu Rayyan A et al. Targeted genomic capture and massively parallel sequencing to identify genes for hereditary hearing loss in Middle Eastern families. Genome Biol, 2011; 12(9): R89

8. Martins FTA, Brownstein Z, Birkan $M$ et al. Identification of deafness genes in Israeli Jewish and Brazilian families using Next Generation Sequencing platforms. Eur J Hum 2015; 23, Suppl. 1 (European Human Genetics Conference 2015; June 6-9, Glasgow, U.K.).

9. Danial-Farran N, Brownstein Z, Abu-Rayyan A et al. Identification of novel genes and mutations associated with hearing loss in the Middle Eastern Arab population by next generation sequencing. Eur J Hum, 2015; 23, Suppl. 1 (European Human Genetics Conference 2015; June 6-9, Glasgow, U.K.).

10. Roux AF, Faugere V, Moclyn M et al. Prevalence of non-syndromic hearing loss genes in a cohort of French patients. Eur J Hum, 2015; 23, Suppl. 1 (European Human Genetics Conference 2015; June 6-9, Glasgow, U.K.).

11. Boardman S, Mavrogiannis LA, Crinnion L, Watson CM, Charlton RS. Gene panel testing in non-syndromic hearing loss: validation on a British Asian cohort. Eur J Hum, 2015; 23, Suppl. 1 (European Human Genetics Conference 2015; June 6-9, Glasgow, U.K.).

12. Song LJ, Yi YT. Panel base on next-generation sequencing for mutation detection in hearing impairment. Eur J Hum. 2015; 23, Suppl. 1 (European Human Genetics Conference 2015; June 6-9, Glasgow, U.K.).

13. Pollak A, Lechowicz U, Podgorska A et al. Genetically related hearing loss: results of exome sequencing in Polish patients. Eur J Hum, 2015; 23, Suppl. 1 (European Human Genetics Conference 2015; June 6-9, Glasgow, U.K.).

14. Lechowicz U, Pollak A, Podgorska A et al. Profile of TMPRSS3 mutation among Polish patients with nonsyndromic hearing impairment. Eur J Hum, 2015; 23, Suppl. 1 (European Human Genetics Conference 2015; June 6-9, Glasgow, U.K.).

15. Battelino S, Klancar G, Kovac J, Battelino T, Trebusak Podkrajsek K. TMPRSS3 mutations in autosomal recessive nonsyndromic hearing loss. Eur Arch Otorhinolaryngol, 2015 [Epub ahead of print].

16. Abdelfatah N, Mostafa A, Stanton SG, et al. An in-frame deletion in FOXL1 identifies the first gene causing autosomal dominant otosclerosis. Eur J Hum. 2015;23, Suppl. 1 (European Human Genetics Conference 2015; June 6-9, Glasgow, U.K.).

17. Declau F, Van Spaendonck M, Timmermans JP, Michaels L, Liang J, Qiu JP et al. Prevalence of otosclerosis in an unselected series of temporal bones. Otol Neurotol, 2001; 22(5): 596-602.

18. Schrauwen I, Van Camp G. The etiology of otosclerosis: a combination of genes and environment. Laryngoscope, 2010; 120(6): 1195-202.

19. Stanton S, Lucas M, Griffin A et al. The hearing phenotype associated with an in-frame deletion in FOXL1 causing autosomal dominant otosclerosis. Eur J Hum, 2015; 23, Suppl. 1 (European Human Genetics Conference 2015; June 6-9, Glasgow, U.K.).

20. Priyadarshi S, Ray CS, Panda KC, Desai A, Nayak SR, Biswal NC et al. Genetic association and gene expression profiles of TGFB1 and the contribution of TGFB1 to otosclerosis susceptibility. J Bone Miner Res, 2013; 28(12): 2490-7.

21. Girotto G, Scheffer DI, Morgan A et al. NGS revealed PSIP1/LEDGF as a new gene causing sensorineural progressive hearing loss and variable eye phenotypes. Eur J Hum, 2015; 23, Suppl. 1 (European Human Genetics Conference 2015; June 6-9, 2015 Glasgow, U.K.).
22. Pradeepa MM, Sutherland HG, Ule J, Grimes GR, Bickmore WA. Psip1/Ledgf p52 binds methylated histone H3K36 and splicing factors and contributes to the regulation of alternative splicing. PLoS Genet, 2012; 8(5): e1002717.

23. Raz-Prag D, Zeng Y, Sieving PA, Bush RA. Photoreceptor protection by adeno-associated virus-mediated LEDGF expression in the RCS rat model of retinal degeneration: probing the mechanism. Invest Ophthalmol Vis Sci, 2009; 50(8): 3897-906.

24. Ratbi I, Falkenberg KD, Sommen $M$ et al. Heimler syndrome is caused by hypomorphic mutations in the peroxisome-biogenesis genes PEX1 and PEX6. Am J Hum Genet, 2015 [Epub ahead of print].

25. Lima LH, Barbazetto IA, Chen R, Yannuzzi LA, Tsang SH, Spaide RF. Macular dystrophy in Heimler syndrome. Ophthalmic Genet, 2011; 32(2): 97-100.

26. Heimler A, Fox JE, Hershey JE, Crespi P. Sensorineural hearing loss, enamel hypoplasia, and nail abnormalities in sibs. Am J Med Genet, 1991; 39(2): 192-5.

27. Santos-Cortez RL, Lee K, Giese AP, Ansar M, Amin-Ud-Din $\mathrm{M}$, Rehn K et al. Adenylate cyclase 1 (ADCY1) mutations cause recessive hearing impairment in humans and defects in hair cell function and hearing in zebrafish. Hum Mol Genet, 2014; 23(12): 3289-98.

28. Girotto G, Abdulhadi K, Buniello A, Vozzi D, Licastro D, d'Eustacchio A et al. Linkage study and exome sequencing identify a $B D P 1$ mutation associated with hereditary hearing loss. PLoS One, 2013; 8(12): e80323.

29. Diaz-Horta O, Subasioglu-Uzak A, Grati M, DeSmidt A, Foster J II, Cao L et al. FAM65B is a membrane-associated protein of hair cell stereocilia required for hearing. Proc Natl Acad Sci USA, 2014; 111(27): 9864-8.

30. Azaiez H, Decker AR, Booth KT, Simpson AC, Shearer AE, Huygen PL et al. HOMER2, a stereociliary scaffolding protein, is essential for normal hearing in humans and mice. PLoS Genet, 2015; 11(3): e1005137.

31. Gao J, Wang Q, Dong C, Chen S, Qi Y, Liu Y. Whole exome sequencing identified $M C M 2$ as a novel causative gene for autosomal dominant nonsyndromic deafness in a Chinese family. PLoS One, 2015; 10(7): e0133522.

32. Mujtaba G, Schultz JM, Imtiaz A, Morell RJ, Friedman TB, Naz S. A mutation of MET, encoding hepatocyte growth factor receptor, is associated with human DFNB97 hearing loss. J Med Genet, 2015; 52(8): 548-52.

33. Simon M, Richard EM, Wang X, Shahzad M, Huang VH, Qaiser TA et al. Mutations of human NARS2, encoding the mitochondrial asparaginyl-tRNA synthetase, cause nonsyndromic deafness and Leigh syndrome. PLoS Genet, 2015; 11(3): e1005097.

34. Yan D, Zhu Y, Walsh T, Xie D, Yuan H, Sirmaci A et al. Mutation of the ATP-gated $\mathrm{P} 2 \mathrm{X}(2)$ receptor leads to progressive hearing loss and increased susceptibility to noise. Proc Natl Acad Sci USA, 2013; 110(6): 2228-33.

35. Azaiez H, Booth KT, Bu F, Huygen P, Shibata SB, Shearer AE et al. TBC1D24 mutation causes autosomal-dominant nonsyndromic hearing loss. Hum Mutat, 2014; 35(7): 819-23.

36. Li J, Zhao X, Xin Q, Shan S, Jiang B, Jin Y et al. Whole-exome sequencing identifies a variant in TMEM132E causing autosomal-recessive nonsyndromic hearing loss DFNB99. Hum Mutat, 2015; 36(1): 98-105.

37. Bedoyan JK, Schaibley VM, Peng W, Bai Y, Mondal K, Shetty AC et al. Disruption of RAB40AL function leads to MartinProbst syndrome, a rare X-linked multisystem neurodevelopmental human disorder. J Med Genet, 2012; 49(5): 332-40. 
38. Ołdak M, Ruszkowska E, Pollak A, Sobczyk-Kopcioł A, Kowalewski C, Piwońska A et al. A note of caution on the diagnosis of Martin-Probst syndrome by the detection of the p.D59G mutation in the RAB40AL gene. Eur J Pediatr, 2015; 174(5): 693-6.

39. Ołdak M, Ścieżyńska A, Młynarski W, Borowiec M, Ruszkowska E, Szulborski K et al. Evidence against RAB40AL being the locus for Martin-Probst X-linked deafness - intellectual disability syndrome. Hum Mutat, 2014; 35(10): 1171-4.

40. Donaudy F, Ferrara A, Esposito L, Hertzano R, Ben-David O, Bell RE et al. Multiple mutations of MYO1A, a cochlear-expressed gene, in sensorineural hearing loss. Am J Hum Genet, $2003 ; 72(6)$ : 1571-7.

41. Eisenberger T, Di Donato N, Baig SM, Neuhaus C, Beyer A, Decker $\mathrm{E}$ et al. Targeted and genomewide NGS data disqualify mutations in MYO1A, the "DFNA48 gene", as a cause of deafness. Hum Mutat, 2014; 35(5): 565-70.
42. Rivera T, Sanz L, Camarero G, Varela-Nieto I. Drug delivery to the inner ear: strategies and their therapeutic implications for sensorineural hearing loss. Curr Drug Deliv, 2012; 9(3): 231-42.

43. Park YH, Wilson KF, Ueda Y, Tung Wong H, Beyer LA, Swiderski DL et al. Conditioning the cochlea to facilitate survival and integration of exogenous cells into the auditory epithelium. Mol Ther, 2014; 22(4): 873-80.

44. Crispino G, Di Pasquale G, Scimemi P, Rodriguez L, Galindo Ramirez F, De Siati RD et al. BAAV mediated GJB2 gene transfer restores gap junction coupling in cochlear organotypic cultures from deaf Cx26Sox10Cre mice. PLoS One, 2011; 6(8): e23279.

45. Yu Q, Wang Y, Chang Q, Wang J, Gong S, Li H, Lin X. Virally expressed connexin 26 restores gap junction function in the cochlea of conditional Gjb2 knockout mice. Gene Ther, 2014; 21(1): 71-80.

46. Fukui H, Raphael Y. Gene therapy for the inner ear. Hear Res, 2013; 297: 99-105. 